\title{
STUDI LITERATUR BASIS DATA SQL DAN NOSQL
}

\author{
Widya Nita Suliyanti \\ Program Studi Teknik Informatika, Sekolah Tinggi Teknik PLN \\ Jln. Lingkar Luar Barat, Duri Kosambi, Cengkareng, Jakarta Barat, 11750 \\ Telp. (021) 5440342 \\ E-mail: widya@sttpln.ac.id
}

\begin{abstract}
With the increasing need to store large amounts of unstructured and semi-structured data, the database that used to be mostly using SQL technology, began using the NoSQL database. The purpose of this paper is to conduct a literature study of the characteristics, advantages and disadvantages of $S Q L$ and NoSQL databases. This literature study shows that there are differences in SQL databases and based on characteristics (ACID for SQL vs. BASE and CAP for NoSQL); data model (relational for SQL and key-value for NoSQL); data structure (structured for $S Q L$ and non- or semi-structured for NoSQL); process (subquery, join and grouping / aggregation and complex queries faster only for $S Q L$ ); and the number of servers used (single large server for $S Q L$ and multiple multiple levels for NoSQL). A literature review for further SQL and NoSQL applications is needed in the future.
\end{abstract}

Keywords: SQL, NoSQL, database, characteristics

\begin{abstract}
ABSTRAK
Dengan bertambahnya kebutuhan untuk menyimpan jenis data tidak terstruktur dan semi terstruktur dalam jumlah besar, basis data yang tadinya sebagian besar menggunakan teknologi SQL, mulai menggunakan basis data NoSQL. Tujuan dari paper ini adalah untuk melakukan studi literature mengenai karakteristik - karakteristik, kelebihan dan kekurangan dari basis data SQL dan NoSQL. Studi literature ini menunjukkan bahwa terdapat perbedaan basis data SQL dan berdasarkan karakteristik (ACID untuk SQL vs BASE dan CAP untuk NoSQL); model data (relasional untuk SQL dan key-value untuk NoSQL); struktur data ( terstruktur untuk SQL dan non- atau semi struktur untuk NoSQL); proses (subquery, join and grouping/aggregation dan query yang kompleks dengan lebih cepat hanya untuk $S Q L)$; dan jumlah server yang digunakan (server besar tunggal untuk $S Q L$ dan servel kecil multiple untuk NoSQL). Review literature untuk aplikasi SQL dan NoSQL lebih lanjut diperlukan di masa datang.
\end{abstract}

Kata Kunci: SQL, NoSQL, basis data, karakteristik 


\section{PENDAHULUAN}

SQL (Structured Query Language) pada awalnya disebut dengan SEQUEL dikembangkan di IBM oleh Donald D. Chamberlin dan Raymond F. Boyce pada tahun 1970 [1]. SQL digunakan untuk memanipulasi dan menarik data yang tersimpan pada IBM database management system yang disebut dengan System R. SQL ini dikembangkan setelah mempelajari model rasional dari manajemen basis data yang ditemukan oleh E. F Codd di awal tahun 1970 [2].

Seiring dengan perkembangan teknologi, di awal abad 21, muncul technologi baru yang dikenal dengan NoSQL (no SQL atau Not only $S Q L$ atau bukan relasional). Teknology NoSQL ini terutama dipicu oleh oleh kebutuhan- kebutuhan perusahaan Web 2.0 yang mengacu pada website dengan titik berat pada isi yang dibuat oleh user (user-generated content), penggunaan yang mudah (ease of use) dan sesuai dengan sistem yang digunakan oleh end user [3]. Walaupun kedua technologi ini sudah banyak digunakan, namun belum ada studi literature untuk membahas manfaat dan kelemahan basis data SQL dan NoSQL.

\section{METODE PENELITIAN}

Literatur yang membahas basis data SQL and NoSQL dicari dengan menggunakan kata kunci: SQL, NoSQL, database dari database berbagai publikasi. Publikasi yang diterbitkan sampai tahun 2019 yang memenuhi kriteria inklusi (sistem/aplikasi/implementasi yang menggunakan basis data SQL atau NoSQL atau keduanya) SQL, NoSQL dan database dimasukkan ke dalam studi literature ini.

\section{HASIL DAN PEMBAHASAN}

Terdapat 4 literature yang dimasukkan dalam review untuk membahas mengenai basis data SQL dan NoSQL dengan hasil sebagai berikut:

\subsection{Basis Data SQL}

Basis data SQL mempunyai karakteristik ACID (Atomic, Consistent, Isolation dan Durability) [4]. Atomic adalah apabila ada sebuah transaksi yang terdiri dari dua atau lebih komponen informasi, semua komponennya harus disimpan atau semua komponennya tidak disimpan. Tidak ada sebagian saja komponen yang disimpan atau tidak disimpan. Consistent adalah data yang disimpan tidak boleh melanggar integritas basis data. Perubahan data yang mengalami gangguan dibatalkan untuk memastikan basis data berada dalam kondisi sama seperti sebelum ada perubahan. Isolation adalah sebuah transaksi tidak dipengaruhi oleh transaksi lain yang sedang berjalan. Hal ini untuk mencegah terjadinya benturan data antar transaksi. Durability adalah apabila transaksi sudah disimpan di basis data secara permanen, untuk seterusnya transaksi tersebut ada di basis data meskipun terjadi kegagalan sistem.

Basis data SQL memiliki kelebihan yaitu dapat memproses query yang kompleks dalam waktu yang relatif lebih singkat dan mendukung konsistensi [5] . Selain itu basis data SQL dapat melakukan subquery, joins dan grouping/aggregation [6]. Basis data SQL dirancang untuk berjalan pada satu server sehingga apabila basis data memerlukan tempat penyimpanan data yang besar maka diperlukan server dengan ukuran besar. Basis data SQL mempunyai kekurangan dalam mendistribusikan data dan beban secara merata terhadap sebanyak mungkin server [7] .

\subsection{Basis Data NoSQL}

Basis data NoSQL mempunyai karakteristik BASE (Basically, Available, Soft state and Eventual Consistency) yang merupakan kebalikan dari ACID pada basis data SQL. Setelah transaksi yang konsisten, keadaan (state) yang didapat adalah keadaan sementara (soft state) bukan keadaan tetap (solid state). Fokus utama dari BASE adalah ketersediaan permanen. Karakteristik berikutnya adalah CAP (Consistency, Availability dan Partition) yang mempunyai tiga prinsip utama: 1) Data tersedia pada semua mesin harus sama di semua aspek dan update 
harus dilakukan terhadap semua mesin. 2) Data harus tersedia secara permanen dan harus dapat diakses setiap saat. 3) Pada saat terjadi kegagalan mesin atau kesalahan lainnya, basis data tetap bekerja dengan baik tanpa ada pekerjaan yang berhenti.

Basis data NoSQL tidak menggunakan model data rasional, dapat menyimpan data dalam ukuran besar dan juga memperbolehkan data untuk disimpan didalam record yang tidak mempunyai skema yang sudah tertentu. Basis data NoSQL dibagi dalam beberapa jenis basis data: 1) Basis data Key-value adalah kombinasi antara key dan value yang merupakan basis data inti dari semua basis data NoSQL. 2) Basis data Document Store adalah basis data yang menggunakan record sebagai dokumen. Record ini menyimpan dokumen tidak berstruktur (unstructured) atau semi terstruktur (semi structured documents). Setiap dokumen terdiri dari satu set key dan value, hampir sama dengan basis data Key-value. 3) Basis data berbentuk kolom adalah basis data yang berorientasi kolom. Terdiri dari 2 jenis basis data. a) Tempat penyimpan data dengan kolom lebar (wide-column data store) dan Basis data berorientasi kolom. 4) Basis data grafis terdiri dari node, properties (karakteristik) dan edge [4].

Basis data NoSQL memiliki kelebihan dapat memproses data terstruktur, semi terstruktur dan tidak terstruktur dalam jumlah besar yang sering disebut sebagai Big Data dengan kecepatan tinggi, menggunakan skema yang fleksibel dan basis data terdistribusi (distributed database). Namun basis data SQL juga memiliki kelemahan yaitu untuk memproses operasi yang kompleks membutuhkan waktu yang lama dan tidak mempunyai dukungan untuk konsistensi [5]. Selain itu basis data NoSQL tidak dapat memproses subqueries, joins and grouping/aggregation.

Perbandingan singkat antara basis data SQL dan NoSQL.

Tabel 1. Perbandingan antara basis data SQL dan NoSQL

\begin{tabular}{|c|c|c|c|}
\hline No & Nama Item & Basis Data SQL & Basis Data NoSQL \\
\hline 1 & Karakteristik & ACID & BASE, CAP \\
\hline 2 & Data & Terstruktur & $\begin{array}{lll}\text { Tidak terstruktur, } & \text { semi } \\
\text { terstruktur }\end{array}$ \\
\hline 3 & Mesin & Tunggal & Banyak \\
\hline 4 & Basis Data & Terpusat & Terdistribusi \\
\hline 5 & Kelebihan & $\begin{array}{l}\text { Dapat memproses } \\
\text { subquery, join dan } \\
\text { grouping/aggregation dan } \\
\text { query yang kompleks dengan } \\
\text { cepat }\end{array}$ & $\begin{array}{l}\text { Dapat mendistribusikan data dan } \\
\text { beban secara merata terhadap } \\
\text { sebanyak mungkin server }\end{array}$ \\
\hline 6 & Kekurangan & $\begin{array}{l}\text { Tidak dapat } \\
\text { mendistribusikan data dan } \\
\text { beban secara merata terhadap } \\
\text { sebanyak mungkin server }\end{array}$ & $\begin{array}{l}\text { - Tidak dapat memproses } \\
\text { subquery, join dan grouping/ } \\
\text { aggregation } \\
\text { - Membutuhkan waktu yang } \\
\text { lama untuk memproses query } \\
\text { yang kompleks }\end{array}$ \\
\hline
\end{tabular}

\section{KESIMPULAN}

Studi literature menunjukkan bahwa terdapat perbedaan karakteristik basis data SQL dan NoSQL (ACID untuk SQL vs BASE dan CAP untuk NoSQL). Model data SQL berdasarkan model data relasional sedangkan NoSQL berdasarkan key-value. Basis data SQL lebih sesuai untuk data terstruktur sedangkan basis data NoSQL lebih sesuai untuk data tidak terstruktur dan data semi terstruktur (misalnya Big Data). Basis data SQL lebih terpusat pada mesin tunggal sedangkan basis data SQL dapat terdistribusi pada banyak mesin/server. Basis data SQL dapat memproses subquery, join and grouping/aggregation dan query yang kompleks dengan lebih cepat, sedangkan basis data NoSQL tidak dapat memproses query tersebut di atas. Studi Literature untuk aplikasi SQL dan NoSQL lebih lanjut diperlukan di masa datang untuk dapat meningkatkan efektivitas dan effisiensi kedua sistem tersebut. 


\section{DAFTAR PUSAKA}

1. Donald D. Chamberlin and R.F. Boyce. SEQUEL: A structured English query language. in Proceeding of the 1974 ACM SIGFIDET (now SIGMOD) workshop on Data description, access and control. 1974. Michigan, USA.

2. Codd, E.F., A Relational Model of Data for Large Shared Data Banks, in Communications of the ACM. June 1970, ACM: New York, USA. p. 377-387.

3. Mohan, C. History repeats itself: sensible and NonsenSQL aspects of the NoSQL hoopla. in 16th International Conference on Extending Database Technology. 2013. Genoa, Italy: ACM.

4. Vatika Sharma and M. Dave, SQL and NoSQL Databases. International Journal of Advanced Research in Computer Science and Software Engineering, August 2012. 2(8): p. 20-27.

5. Yishan Li and S. Manoharan, A performance comparison of SQL and NoSQL databases, in 2013 IEEE Pacific Rim Conference on Communications, Computers and Signal Processing (PACRIM). 2013: Victoria, Canada.

6. Lawrence, R., Integration and Virtualization of Relational SQL and NoSQL Systems including MySQL and MongoDB, in 2014 International Conference on Computational Science and Computational Intelligence. 2014, IEEE: Las Vegas, NV, USA. p. 285-290.

7. Cattell, R., Scalable SQL and NoSQL Data Stores. ACM Special Interest Group on Management of Data, 2011. 39(4): p. 12-27. 